\title{
Impact of Total Quality Management Practices on Quality Performance: A Case Study on Armament Manufacturing Industry
}

\author{
Hagos Berhane $^{1}$ and Pramila Devi Maganti ${ }^{2}$ \\ ${ }^{1}$ Department of Production Engineering, College of Engineering, Defense University, Bishoftu, Ethiopia \\ ${ }^{2}$ Department of Mechanical Engineering, College of Engineering, Andhra University, Visakhapatnam, Andra Pradesh, India \\ E-Mail: hagos_berhane@yahoo.com, pramiladevi_m@yahoo.co.in
}

\begin{abstract}
Total quality management (TQM) has been widely considered as the strategic, tactical and operational tool in the quality management research field. It is one of the most applied and well accepted approaches for business excellence besides continuous quality improvement, six sigma, just-intime, and supply chain management approaches. This study investigated impact of TQM practices on quality performance in an armament manufacturing industry in Ethiopia. The quantitative approach and the survey method of collecting data were used. The five point Likert scale structured questionnaire was administered through the face-to-face method of collecting data. 340 questionnaires were randomly distributed to employees who are working in different factories in the two armament manufacturing industry. Eight factors related to TQM practices were initially selected as independent variables viz., leadership, customer focus, continuous improvement, employee involvement, training and education, supplier management, strategic quality planning, information analysis, and quality performance as dependent variable in the proposed model. Raw data was analysed with the help with SPSS software (version - 20). Mean, standard deviation, exploratory factor analyses, correlation, and multiple regression analyses were used to find the impact of TQM practices on quality performance. The results of this study supported the model proposed $\left(R^{2}=0.378, F=36.292, p=\right.$ 0.000). This study has shown that only three (viz., leadership, customer focus, and information analysis) of TQM practices significantly $(p<0.05)$ have positive impact on quality performance. It is recommended that industry should continue to implement TQM practices with all variables to improve quality performance. Industry should improve continuous improvement, employee involvement, training and education, supplier management, strategic quality planning more to overcome the barriers that prevent effective implementation of TQM practices.
\end{abstract}

Keywords: Total Quality Management, Quality Performance, Manufacturing Industry, Regression Analysis

\section{INTRODUCTION}

In organizations, managers/leaders acquire energy through satisfying customer needs and organizational survival which is the main philosophy of total quality management (TQM). TQM is a holistic quality improvement approach to firms for the purpose of improving performance in terms of quality and innovation for the last two decades. Organizations which are used TQM generate many benefits such as higher quality products, more satisfied customers, reduced costs, improved financial, quality and innovation performance and in addition to these improved employee satisfaction. Moreover, if TQM is implemented successfully, it provides a competitive advantage as well [1].

TQM has become most widely used management acronym and is considered as the buzz word in the management practices. It has been well accepted by managers and quality practitioners as a change management quality approach [2]. It plays a vital role in the development of management practices [3, 4].

\section{A. Total Quality Management}

TQM is one of the quality-oriented approaches that many organizations imply. TQM is one of the most popular and durable management concepts [5]. Due to the absence of a uniform definition of TQM, defining TQM is quite problematic [1]. Well accepted definitions of TQM in the literature based on "quality gurus" [6-9] views and prescriptions.

TQM is a multidimensional construct. TQM consists of several activities. Different researchers have adopted different TQM activities for testing its effect on financial or non-financial performance. These activities are management leadership, role of the quality department, training, employee relations, quality data and reporting, supplier quality management, product service design, process management, strategic planning, customer focus, information technology and analysis, people management $[10,11]$.

\section{B. Relationship between TQM Practices and Quality Performance}

The links between TQM and performance have been investigated by numerous scholars. While examining the relationship between TQM and performance scholars have used different performance types such as financial, innovative, operational and quality performance. Although the effects of TQM on various performance types are inconsistent, quality performance generally indicated strong and positive relations [11].

Kaynak (2003) [12] revealed the indicators of quality performance which is relevant to TQM. TQM practices help 
to promote quality performance. The indicators for quality performance are product/service quality, productivity, cost of scrap and rework, delivery lead-time of purchased materials, and delivery lead-time of finished products to customers. The aim of TQM activities such as employee involvement is to promote the human aspects of the quality system in order to adapt changing environment [13]. Customers focus and process management represents the major components of quality [14]. The quality is important for customers. Wilkinson et al. (1998), suggest that; "in terms of TQM, the conception of quality should meet customer requirements" [15].

One of the main elements of TQM is the process management. Process management improves the quality of the product in the production stage [16]. The empirical studies show that process management directly and positively affects product quality. In addition, management leadership contributes to quality performance through accepting quality culture to employees. Since 1980s, top managers incorporated quality to strategic planning process for gaining competitive advantage [17]. The other TQM activity which has significantly positive relationship with quality performance is factual approach to decision making. Ho et al. (2001), and Choi and Eboch (1998), have found that information and quality data analysis is significantly, positively related to quality performance [18-20]. In contrast the relationship between continual improvement and quality performance is not significantly [21]. Prajogo and Brown (2004) draw our attention to the strong and positive relationship between TQM activities and quality performance [22]. And Prajogo and Sohal (2004) emphasized the importance of TQM on quality performance [14].

A considerable body of empirical evidence suggests that TQM implementation improves quality performance of the company. It has been measured in various ways and found that the quality management model and specific practices, which best predict performance varies across the world [2325].

The research framework for quality management proposed by Flynn (1984) suggested that the inputs of this framework are the quality management practices while quality performance represents outcomes [26]. Further, product design process, process flow management, and topmanagement support have significant correlation with quality performance [27].

Prajogo and Brown (2004) conducted an empirical study within Australian organizations to investigate the relationship between TQM practices and quality performance, and the results indicated a strong and positive linkage [28]. A study on ISO 9000 certified organizations of Taiwan performed by [29] examined linkage between six QM practices and quality performance. He found customer focus as the most powerful discriminated practice of quality performance while remaining five practices showed low discriminating powers [29].
Brah and Tee (2002) examined the relationship between TQM constructs and organization performance by measuring quality performance of Singapore companies. They found that implementation of TQM leads to quality performance and have positive correlation [30]. Another study based on the comparative analysis of TQM practices and quality performance between Australian manufacturing and service firms, Prajogo (2005) reported that there exist no significant differences in the level of most of the TQM practices and quality performance between two sectors [31]. A study utilizing structural equation modeling approach by Sanchez-Rodriguez et al. (2006) provided the insights into the current information technology and TQM theory and practice on operational and quality performance. They found TQM initiatives generate significant positive gains in operational and quality performance [32].

Most of the previous studies report that overall TQM practices have positively been related to quality performance [33-36]. Thus, the following hypothesis is proposed:

H1: TQM practices have a positive influence on quality performance.

\section{RESEARCH METHODOLOGY}

\section{Data Collection and Demographic Distribution of the Sample}

The demographic properties which are asked to the participants are prepared by the researchers. The present study used a survey conducted among 340 employees (more than the sample size) of two industry working at different level i.e., operators, engineers, supervisors, team leaders, managers, and general managers. Simple random sampling technique was used.

\section{Measures}

The questionnaire in this study was developed by using scales adopted from prior studies. All constructs are measured using five - point Likert scales (from strongly disagree $=1$ to strongly agree $=5$ ).

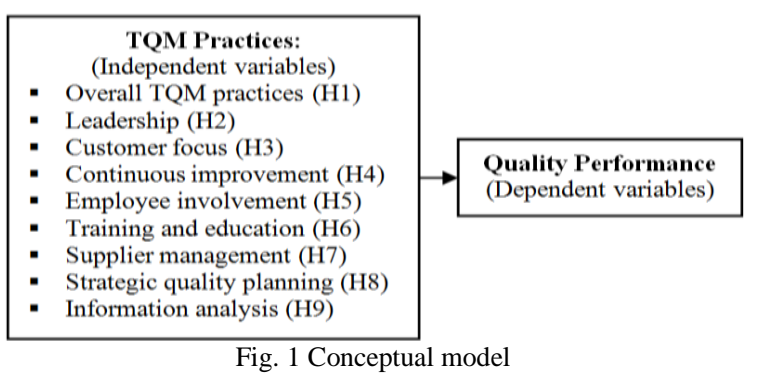

The questionnaire was having 72 items related to TQM practices viz., eight factors are leadership (LS), customer focus $(\mathrm{CF})$, knowledge and continuous improvement (KI), employee involvement (EI), training and education (TE), supplier management (SM), strategic quality planning (SP), 
and information analysis (IA) and 13 items related to quality performance which were adopted from several related studies. In order to examine how TQM practices impact quality performance in manufacturing industry, this study develops a theoretical TQM practices model as shown in Fig.1.

\section{RESULTS}

\section{A. Results of the EFA, Reliability, Descriptive Statistics and Correlations}

SPSS software - 20 was used for the statistical analysis of the collected data. Exploratory factor analysis with principal component by varimax rotation, was performed separately to find out the factor structure of dependent (Quality performance-QP) and independent variables (TQM practices).

For the independent variable since some items were below 0.50 or are having collinearity with more than one factor, and some factors contains one item, it is continued to perform factor analyzing by removing the items one by one till the ideal table. After conducting exploratory factor analysis and reliability analysis, the final measurement instrument included 28 TQM practices and 6 quality performance items.

Results revealed that the TQM practices items explained 61.84 per cent of the total variance, with the Eigen value of more than one. Leadership (LS) included 9 items that explained 15.21 per cent of the total variance, training and education (TE) included 8 items that explained 14.24 per cent of the total variance, quality performance (QP) included 6 items that explained 11.21 per cent of the total variance, customer focus $(\mathrm{CF})$ included 5 items that explained 8.49 per cent of the total variance, employee involvement (EI) included 4 items that explained 7.41 per cent of the total variance, and information analysis (IA) included 2 items that explained 5.25 per cent of the total variance. The factor of continuous improvement (CI), supplier management (SM), and strategic quality planning (SQP) were eliminated after exploratory factor analysis.

The factors had content validity since their items were adapted from the previous studies in the literature. Table 2 lists descriptive statistics, Cronbach's alpha values, and Pearson correlations for the variables in the research model. All factor loadings were greater than 0.50 thresholds. This means that unidimensionality and construct validity of the measures were satisfied. Cronbach's alpha values of the factors were between 0.672 and 0.904 , which surpasses the 0.60 threshold. This showed that all TQM practices and quality performance scales had acceptable reliabilities.

In this study, an industry achieving a level of TQM implementation above the mean value of 3 is regarded as having a "positive" level of TQM practices used. This means that the industry has taken conscientious efforts to
TQM practices or to implement TQM. Whereas, an industry with a level of TQM practices implementation below the mean value of 3 would indicate that it lacks the efforts to TQM practices or to implement TQM [37].

Means and standard deviations (SD) for each factor and a correlation analysis were conducted to investigate the relationship between dependent and independent variables (Table 1). According to correlation analysis, all variables are correlated with each other. In order to investigate the reliability scores factors, the Cronbach alpha scale is used. Regarding to the results of the statistical tests for reliability and validity, it is assumed that the factors of the variables are sufficiently valid and reliable to test hypothesis. The mean values of TQM practices were less than 3 (Table I). This means that the industry lacks the efforts to TQM practices or to implement TQM practices.

TABle I DESCRIPTIVE STATISTICS, CRONBACH's AlPHA, AND BIVARIATE CORRELATION For THE VARIABLES IN THE RESEARCH MODEL

\begin{tabular}{|c|c|c|c|c|c|c|c|c|c|}
\hline Factors & Meall & SD & LS & $\mathrm{TE}$ & $\mathrm{CF}$ & EI & IA & $Q P$ & TQM \\
\hline LS & 2.365 & 0.7385 & $(0.904)$ & & & & & & \\
\hline $\mathrm{TE}$ & 2.705 & 0.800 & $0.542^{2 *}$ & $(0.895)$ & & & & & \\
\hline $\mathrm{CF}$ & 2.275 & 0.658 & $0.63^{8 * *}$ & $0.561^{*}$ & $(0.786)$ & & & & \\
\hline EI & 2.431 & 0.762 & $0.519^{* * *}$ & $0.561^{1}$ & $0.554^{* *}$ & $(0.809)$ & & & \\
\hline IA & 2.371 & 0.770 & $0.361^{1 *}$ & $0.448^{*}$ & $0.355^{4}$ & $0.438^{* *}$ & $(0.672)$ & & \\
\hline$Q P$ & 2.419 & 0.702 & $0.544^{* * *}$ & $0.566^{*}$ & $0.500^{*}$ * & $0.454^{* *}$ & $0.386^{* *}$ & $(0.864)$ & \\
\hline TQM & 2.429 & 0.576 & $0.786^{6 * *}$ & $0.813^{* \text { 䋨 }}$ & $0.789^{* * * *}$ & $0.797^{* \text { 蜶 }}$ & $0.681^{* *}$ & $0.635^{* *}$ & $(0.830)$ \\
\hline
\end{tabular}

Before performing principal component analysis, the homogeneity of the data for sampling adequacy was measured. Table II shows a data matrix for the analysis of TQM practices and quality performance (QP). Table 3 shows, the Kaiser - Meyer - Olkin (KMO) measure is 0.960 , which is greater than the "middling" value of 0.7 , and the result of Barlett's test of Sphericity is less than 0.05 (i.e., chi-square $=12643.963$, df $=1035$, sig. $=0.000$ ). Thus, the data have homogeneity and adequacy for principal component analysis and also our sample is suitable for the hypothesis analysis.

TABle II Data Matrix For The ANAlysis Of TQM Practices AND QUALITY PERFORMANCE

\begin{tabular}{|l|l|c|}
\hline \multicolumn{2}{|c|}{ KMO Measure of Sampling Adequacy } & 0.917 \\
\hline \multirow{3}{*}{$\begin{array}{l}\text { Bartlett's Test of } \\
\text { Sphericity }\end{array}$} & Approx. Chi - Square & 4503.568 \\
\cline { 2 - 3 } & Degree of Freedom (df) & 561 \\
\cline { 2 - 3 } & Significance (Sig.) & 0.000 \\
\hline
\end{tabular}

Factor analysis (Table III) is used for the validity and Cronbach alpha scale is used to estimate the reliability of the scales. Correlation and regression analysis are conducted to analyze the hypotheses of the study. According to Table I, all variables are found to be higher than $0.50(\mathrm{r}>0.40)$, so all items took place in the factor analysis. 
TABLE III FACTOR LOADINGS OF THE TQM AND QUALITY PeRformanCE VARIABLES

\begin{tabular}{|c|c|c|c|c|c|c|}
\hline \multicolumn{7}{|c|}{ Rotated Component Matrix ${ }^{a}$} \\
\hline \multirow{2}{*}{ Items } & \multicolumn{6}{|c|}{ Component } \\
\hline & 1 & 2 & 3 & 4 & 5 & 6 \\
\hline LS5 & 0.762 & & & & & \\
\hline LS4 & 0.720 & & & & & \\
\hline LS3 & 0.716 & & & & & \\
\hline LS2 & 0.702 & & & & & \\
\hline LS12 & 0.692 & & & & & \\
\hline LS10 & 0.677 & & & & & \\
\hline LS7 & 0.634 & & & & & \\
\hline LS1 & 0.621 & & & & & \\
\hline LS11 & 0.466 & & & & & \\
\hline TE4 & & 0.730 & & & & \\
\hline TE5 & & 0.727 & & & & \\
\hline TE8 & & 0.711 & & & & \\
\hline TE6 & & 0.696 & & & & \\
\hline TE9 & & 0.679 & & & & \\
\hline TE7 & & 0.676 & & & & \\
\hline TE3 & & 0.618 & & & & \\
\hline TE1 & & 0.589 & & & & \\
\hline QP5 & & & 0.783 & & & \\
\hline QP7 & & & 0.749 & & & \\
\hline QP6 & & & 0.746 & & & \\
\hline QP4 & & & 0.676 & & & \\
\hline QP9 & & & 0.628 & & & \\
\hline QP8 & & & 0.570 & & & \\
\hline CF1 & & & & 0.716 & & \\
\hline $\mathrm{CF} 2$ & & & & 0.601 & & \\
\hline CF10 & & & & 0.600 & & \\
\hline CF4 & & & & 0.579 & & \\
\hline CF6 & & & & 0.559 & & \\
\hline EI12 & & & & & 0.786 & \\
\hline EI11 & & & & & 0.747 & \\
\hline EI14 & & & & & 0.663 & \\
\hline EI15 & & & & & 0.466 & \\
\hline IA2 & & & & & & 0.793 \\
\hline IA1 & & & & & & 0.663 \\
\hline Eigenvalue & 12.44 & 2.44 & 1.92 & 1.58 & 1.38 & 1.25 \\
\hline Cum. Var. Ex. & & & & & & \\
\hline \multicolumn{7}{|c|}{$\begin{array}{l}\text { Extraction Method: Principal Component Analysis. } \\
\text { Rotation Method: Varimax with Kaiser Normalization. }\end{array}$} \\
\hline \multicolumn{7}{|c|}{ a. Rotation converged in 7 iterations. } \\
\hline Note: Cum. Va & r. Ex. = & Cumul & ative va & ariance & explain & \\
\hline
\end{tabular}

B. Results of the Regression Analyses between TQM Practices and Quality Performance

Table IV, present the result of the regression analysis between the overall TQM practices (index) and quality performance (QP). In regression Table III, the regression model is statistically significant $\left(\mathrm{R}_{\text {adj. }}^{2}=0.415, \mathrm{~F}=173.635\right.$, $\mathrm{p}<0.001)$ and TQM index is significantly and positively related to quality performance (QP). This shows that overall TQM practices (H1) in general, improve industry quality performance.

Table $\mathrm{V}$, present the result of the regression analyses between the TQM practices and quality performance (QP). In regression Table III, the regression model is statistically significant $\left(\mathrm{R}_{\text {adj. }}^{2}=0.416, \mathrm{~F}=35.554, \mathrm{p}<0.001\right)$. The coefficient of multiple determination $\left(\mathrm{R}^{2}\right)$ shows the proportion of variation of the dependent variable accounted for by the independent variables in the regression model. According to Cohen (1988), $\mathrm{R}^{2}$ value of regression model greater than either 0.15 or 0.35 can be interpreted as medium effect or strong effect, respectively [38].

A value of variance inflation factor higher than five (or Tolerance less than 0.2) indicates the presence of multicollinearity. Tables II and III, shows that tolerance is greater than 0.2 and variance inflation factor is less than 5 . Hence, there is no presence of multicollinearity.

TABLE IV TQM INDEX AND QuALity PERFormance REgRESSION ANALYSIS RESULTS

\begin{tabular}{ccccccccc}
\hline DV & $\beta$ & $\mathrm{t}$ & $\mathrm{P}$ & Result & $\mathrm{R}_{\text {adj }}^{2}$ & $\mathrm{~F}$ & $\mathrm{~T} 0 \mathrm{l}$ & $\mathrm{VIF}$ \\
\hline $\mathrm{QP}$ & 0.787 & 13.177 & $0.000^{*}$ & Sig. & 0.415 & 173.635 & 1.00 & 1.00 \\
\hline
\end{tabular}

Note: $\mathrm{DV}=$ Dependent variable, $\mathrm{QP}=$ Quality performance, IVs = Independent variables, Table columns contain unstandardized beta coefficients $(* \mathrm{p}<0.05)$, Sig. $=$ Significant, Tol. $=$ Tolerance $(1.00>0.2)$, VIF $=$ Variance inflation factor $(1.00<5)$

TABLE V TQM PRACTICES AND QUALITY PERFORMANCE REgRESSION ANALYSIS RESULTS

\begin{tabular}{lcccccccc}
\hline IVs & $\beta$ & $\mathrm{t}$ & $\mathrm{p}$ & Result & $\mathrm{R}_{\text {adj }}^{2}$ & $\mathrm{~F}$ & Tol. & VIF \\
\hline LS & 0.233 & 3.308 & $0.001^{*}$ & Sig. & 0.416 & 35.554 & 0.483 & 2.070 \\
TE & 0.276 & 4.130 & $0.000^{*}$ & Sig. & & & 0.537 & 1.861 \\
CF & 0.087 & 1.231 & 0.219 & Insig. & & & 0.482 & 2.075 \\
EI & 0.112 & 1.567 & 0.118 & Insig. & & & 0.470 & 2.128 \\
IA & 0.108 & 1.940 & 0.054 & Insig. & & & 0.774 & 1.292 \\
\hline
\end{tabular}

Note $:$ DV $=$ Dependent variable $=$ Quality performance, IVs = Independent variables, Table columns contain unstandardized beta coefficients $(* \mathrm{p}<0.05)$, Sig. = Significant, Tol. $=$ Tolerance $(0.470$ to $0.774>0.2), \mathrm{VIF}=$ Variance inflation factor $(1.292$ to $2.128<5)$

\section{MANAGERIAL IMPLICATIONS}

The positive relationship between TQM practices and quality performance shows the importance of each of these practices to improve sustainability. The reasons of TQM implantations and ISO certification may guide managers on how to motivate employees in these applications in order to improve quality and industry performance. 


\section{CONCLUSION}

TQM is a quality-oriented approach and has effects on quality performance that are supported by leading studies. Dimensions of TQM such as management leadership, process management, employee involvement and customer focus are commonly accepted activities to improve quality performance of firms [13, 15-17, 22]. In this study analysis results shows that parallel to these empirical supports management leadership [17], supplier management [39], customer focus [40], information analysis [40], strategic quality planning [40] dimensions are effective on quality performance. In addition to these, apart from recent studies supplier management and system approach to management are found to be significantly effective. However, some studies [22] found all dimensions acceptable. In this respect this study contributes to the discussion about the most important dimensions.

\section{REFERENCES}

[1] D.I. Prajogo and A.S. Sohal, "TQM and innovation: A literature review and research framework," Technovation, Vol. 21, pp. 539558, 2001.

[2] V. Arumugam, K.B. Ooi and T.C. Fong, "TQM practices and quality management performance-An investigation of their relationship using data from ISO 9001:2000 firms in Malaysia," The TQM Magazine, Vol. 20, No. 6, pp. 636-650, 2008.

[3] I.D. Prajogo and S.A. Sohal, "The relationship between TQM practices, quality performance, and innovation performance: An empirical examination," International Journal of Quality \& Reliability Management, Vol. 20, No. 8, pp. 901-918, 2003.

[4] D.T. Hoang, B. Igel and T. Laosirihongthong, "The impact of total quality management on innovation: Findings from a developing country," International Journal Quality and Reliability Management, Vol. 23, No.9, pp. 1092-1117, 2006

[5] S. Rahman, and P. Bullock, "Soft TQM hard TQM and organizational performance relationships: An empirical investigation," Omega, Vol. 33, pp. 73-83, 2005.

[6] W.E. Deming, "Out of crisis," MIT Press, Cambridge, MA, 1986.

[7] J.M. Juran, Juran on planning for quality, The Free Press, New York, 1988.

[8] P.B. Crosby, Quality is free: The art of making quality certain, McGraw-Hill, New York, 1979.

[9] A.V. Feigenbaum, Total quality control, McGraw-Hill, New York, 1983.

[10] J.V. Saraph, P.G. Benson, and R.G. Schroeder, "An instrument for measuring the critical factors of quality management," Decision Sciences, Vol. 20, No. 4, pp. 810-829, 1989.

[11] D.I. Prajogo, and A.S. Sohal, "The relationship between TQM practices, quality performance, and innovation performance," The International Journal of Quality \& Reliability Management, Vol. 20, No. 8, pp. 901-918, 2003.

[12] H. Kaynak, "The relationship between total quality management practices and their effects on firm performance," Journal of Operations Management, Vol. 21, pp. 405-435, 2003.

[13] N.P. Mielgo, J.M. Poen-Monters, and C.J. Ordas-Vazquez, "Are quality and innovation management conflicting activities?," Technovation, Vol. 29, No. 8, pp. 537-545, 2009.

[14] D.I. Prajogo, A.S. Sohal, "The relationship between TQM practices and quality performance and the role of formal TQM programs: An Australian empirical study," The Quality Management Journal, Vol. 11, pp. 4-31, 2004.

[15] Wilkinson, T. Redman, E. Snape, and M. Marchington, "Managing with Total Quality Management-Theory and Practice," Macmillian Business, Basingstoke, 1998.

[16] E. Sadıkoğlu, and C. Zehir, "Investigating the effects of innovation and employee performance on the relationship between total quality management practices and firm performance: An empirical study of
Turkish firms," International Journal of Production Economics, Vol. 127, No. 1, pp. 13-26, 2010.

[17] H.J. Cho and V. Pucik, "Relationship between innovativeness, quality, growth, profitability, and market value," Strategic Management Journal, Vol. 26, pp. 555-575, 2005.

[18] D.C.K. Ho, V.G. Duck and H.M. Shih, "Total quality management: An empirical test for mediation effect," International Journal of Production Research, Vol. 39, pp. 529-548, 2001.

[19] T.Y. Choi and K. Eboch, "The TQM paradox: Relations among TQM practices, plant performance, and customer satisfaction," Journal of Operations Management, Vol. 17, pp. 59-75, 1998.

[20] E. Sadıkoğlu and C. Zehir, "The relationship between TQM practices and organizational performance: An empirical investigation," International Journal of Production Economics, Vol. 127, pp. 13-26, 2010.

[21] S. Rahman and P. Bullock, "Soft TQM hard TQM and organizational performance relationships: An empirical investigation," Omega, Vol. 33, pp. 73-83, 2005.

[22] D.I. Prajogo and A. Brown, "The relationship between TQM practices and quality performance and the role of formal TQM programs: An Australian empirical study," The Quality Management Journal, Vol. 11, No. 4, pp. 31-42, 2004.

[23] E.E. Adam, M.L. Corbett and E.B. Flores, J.N. Harrison, T.S. Lee, T.S., B.H. Rho, J. Ribera, D. Samson, and R. Westbrook, "An international study of quality management approach and firm performance," International Journal of Operations and

[24] I.D. Prajogo and S.A. Sohal, "Transitioning from total quality management to total innovation management: An Australian case," International Journal of Quality \& Reliability Management, Vol. 21, No. 8, pp. 861-875, 2004.

[25] V. Arumugam, K.B. Ooi and T.C. Fong, "TQM practices and quality management performance- an investigation of their relationship using data from ISO 9001:2000 firms in Malaysia," The TQM Magazine, Vol. 20, No.6, pp. 636-650, 2008.

[26] B.B. Flynn, R. Schroeder and S. Sakakibara, "A framework for quality management research and an associated measurement instrument," Journal of Operations Management, Vol. 11, pp. 339366, 1994.

[27] B.B. Flynn, R. Schroeder and S. Sakakibara, "The impact of quality management practices on performance and competitive advantage," Decision Sciences, Vol. 26, No. 5, pp. 659-692, 1995.

[28] D.I. Prajogo and A. Brown, "The relationship between TQM practices and quality performance and the role of formal TQM programs: An Australian empirical study," Quality Management Journal, Vol. 11, pp. 31-43, 2004.

[29] Y.C. Jeng, "Performance evaluation of ISO 9000 registered companies in Taiwan," The TQM Magazine, Vol. 10, No. 2, pp. 132$138,1998$.

[30] S.A. Brah and S.S.L. Tee, "Relationship between TQM and performance of Singapore companies," International Journal of Quality \& Reliability Management, Vol. 19, No. 4, pp. 356-379, 2002.

[31] D.I. Prajogo, "The comparative analysis of TQM practices and quality performance between manufacturing and service firms," International Journal of Service Industry Management, Vol. 16, pp. 217-228, 2005

[32] C. Sanchez-Rodriguez, F.W. Dewhurst and A.R. Martinez-Lorente, "IT use in supporting TQM initiatives: An empirical investigation," International Journal of Operations and Production Management, Vol. 26, pp. 486-504, 2006.

[33] S. Curkovic, S. Vickery and C. Droge, "Quality-related action programs: their impact on quality performance and firm performance," Decision Sciences, Vol. 31, No. 4, pp. 885-904, 2000.

[34] M.M.F. Fuentes, F.J.L. Montes and L.M. Fern'andez, "Total quality management, strategic orientation and organizational performance: the case of Spanish companies," Total Quality Management and Business Excellence, Vol. 17, No. 3, pp. 303-323,2006.

[35] S.M. Lee, B.H. Rho and S.G. Lee, "Impact of Malcolm baldrige national quality award criteria on organizational quality performance," International Journal of Production Research, Vol. 41, No. 9, pp. 2003-2020, 2003.

[36] K.H. Lai, T.S. Weerakoon and T.C.E. Cheng, "The state of quality management implementation: a cross-sectional study of quality- 
oriented companies in Hong Kong," Total Quality Management, Vol. 13, No. 1, pp. 29-38, 2002.

[37] D.I. Prajogo and S.W. Hong, "The effect of TQM on performance in R\&D environments: a perspective from South Korean firms," Technovation, Vol. 28, No. 12, pp. 855-863, 2008.

[38] J. Cohen, Statistical Power Analysis for the Behavioral Sciences, Lawrence Erlbaum Associates, 2nd edition, 1988.

[39] C. Zehir, Ö.G. Ertosun, S. Zehir and B. Müceldilli, "Total quality management practices' effects on quality performance and innovative performance," International Conference on Leadership, Technology and Innovation Management, Procedia-Social and Behavioral Sciences, Vol. 41, pp. 273-280, 2012.

[40] F. Talib, Z. Rahman and M.N. Qureshi, "The relationship between total quality management and quality performance in the service industry: A theoretical model," International Journal of Business, Management and Social Sciences, Vol. 1, No. 1, pp. 113-128, 2010. 